\title{
POTENTIAL USE OF MUSIC THERAPY ELEMENTS IN MUSIC TEACHING
}

\author{
Martina Metić ${ }^{1}$, Vesna Svalina ${ }^{2}$ \\ ${ }^{1}$ Zdenko Turkovic Elementary School, \\ Kutjevo, Croatia \\ ${ }^{2}$ Music Subdepartment at Faculty of Education, \\ Josip Juraj Strossmayer University of Osijek, Croatia \\ vesna.svalina@gmail.com
}

Received: 2 January 2020

\begin{abstract}
Recent scientific studies have shown that involving children in music activities influences their mental, emotional, and social development; music is, thus, being used increasingly for medical and therapeutic purposes. In order to discover whether some elements of particular methods of music therapy can be applied in music teaching in primary schools, we conducted a qualitative research in which the participants were third-year elementary school pupils in Osijek. To collect the data, we used a systematic observation procedure. Data analysis involved both qualitative and quantitative analyses. The research results show that the introduction of elements of certain methods of music therapy is possible and that pupils are happy to participate in all the activities carried out. In doing so, pupils demonstrate imagination, creativity, independence at work, and willingness to cooperate.
\end{abstract}

Key words: music teaching, primary education, music therapy, improvisational models of music therapy, music activities

\section{Introduction}

According to the Croatian Primary School Curriculum (2006), the goal of music teaching is "to introduce pupils to musical culture, teach the basic elements of music language and develop musical creativity, as well as to establish and adopt values for the (both critical and aesthetic) assessment of music" (Primary School Curriculum, 2006, 66). In the years 1-3, 
topics in music teaching are: singing, music listening, playing an instrument, and elements of musical creativity. In line with these goals, music teaching should provide pupils with a comfortable, stimulating, and active environment that will allow them to experience music as an art form. Therefore, the Croatian Primary School Curriculum (2006) places primary emphasis on introducing pupils to the aesthetic aspect of music. This approach is supported by a lot of music pedagogues from both Croatia and abroad. According to Swanwick, the primary purpose of music education

“... is aesthetic education, which simply means that it cares about quality rather than quantity of experience. It seeks to promote vital responses to life and living, a sense of delight in all objects and events that come before us meaningfully with clarity and power." (Swanwick, 2003, 58)

Rojko (2012) states that music listening is the only area that provides aesthetic education for pupils, and, as such, introduces them to the world of music through actively experiencing musical acts:

"Only by listening to music, not by performing, is it possible to get to know about great music - only by listening one can develop both musical taste and critical attitude towards it." (Rojko, 2012, 71)

According to some approaches, pupils should be allowed to practice music at school for non-musical reasons - to allow them to improve their intellectual and motor abilities as well as their emotional, psychological, and social development (Hallam, 2010; Hurwitz et al., 1975; Rabinowitch et al., 2013; Rauscher et al., 1994; Rickard et al., 2013; Schlaug et al., 2005; Weber et al., 1999). The results of the research conducted in Austrian, German, and Swiss schools have shown that practicing music intensively in schools has a positive influence on reading skills, spatial skills, motivation, and social climate (Hurwitz et al., 1975; Jensen, 2008; Rauscher et al., 1994; Weber et al., 1999), as well as making pupils more emotionally stable, and improving their conflict resolution skills and group cohesiveness (Weber et al., 1999).

When it comes to non-musical effects of musical activities, we can say that the Primary School Curriculum (2006) takes them into account but it does not have a significant role in music teaching. Some Croatian music pedagogues are very highly critical of any attempt to perform activities in music teaching that aim to achieve non-musical effects. Thus, Rojko (2012) states that any activity that does not contribute to aesthetic education is unnecessary in music teaching. This includes singing, playing an instrument and musical creativity activities: 
"When it comes to primitive children playing mainly lousy instruments, children's functional nonartistic singing of all kinds of school, children, social, folk and pop songs, children's musical creativity which, if any, refers to quite a low level of children's musical illiteracy, there is nothing or almost nothing aesthetic. A child's performance of music is not an aesthetic act if it is not an artistic performance. It is not difficult to be convinced that these activities in teaching practice are not even close to that. It is not the teachers' fault and, perhaps, their poor work performance. Raising the class music performance to an aesthetic level is impossible due to several mostly objective, interrelated reasons: because of the large number of pupils in the class, their very distinctive musical abilities and interests, lack of time, and the very nature of artistic musical performance: to be such requires much more work than is usually available." (Rojko, 2012, 23)

\section{Svalina points out that it is good}

"... for teachers to be aware of the possible non-musical effects of music. Knowing that it is possible to develop other abilities in addition to music, they will enable children to participate more often in musical activities, not only in the teaching of music culture, but also in some other subjects." (Svalina, 2015, 238-239)

Non-musical effects are also achieved through music therapy procedures, which are usually intended for children or adults who have certain difficulties (learning or communication difficulties, certain physical injuries, problems with expressing emotions, etc.), but it can also be implemented with people who do not have severe difficulties. The purpose of music therapy is not to learn about music, but to provide communication to help an adult or child "strengthen their physical, mental, social, and emotional health" (Svalina, 2009, 145).

Music therapy methods can be divided into two basic groups: active and receptive. The former are applied when children or adults are actively involved in singing, movement or playing, whereas the latter are those that involve experiencing music through listening (Bruscia, 1988; Svalina, 2009; Škrbina, 2013). Active methods are based on an active approach and musical improvisation. Therefore, Bruscia (1988) calls them improvisational models of music therapy and divides them into structured and unstructured improvisational models. The structured ones (Figure 1) include methods characterized by a strict structure in which the course of musical activity is precisely defined. These methods are mostly implemented in groups (Bruscia, 1988; Svalina; 2009; Škrbina, 2013). In methods belonging to the group of unstructured improvisational models (Figure 1) very little is predetermined. These methods are 
most commonly implemented individually, which enables individuals to direct their musical activities in whichever direction that is most convenient for them. The therapist seeks to establish communication and adapts to the situation (Bruscia, 1988; Svalina, 2009; Škrbina, 2013).

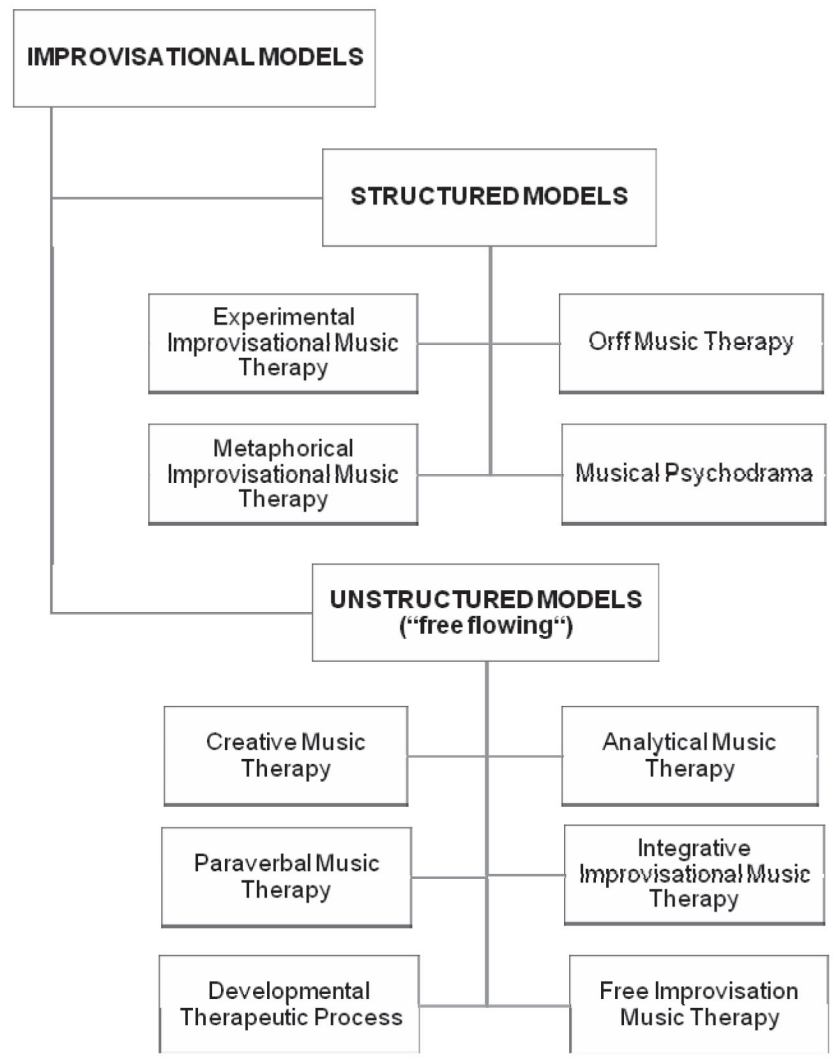

Figure 1. Improvisational models by Kennet E. Bruscia (1988)

For the purposes of this paper, we have singled out methods that we consider applicable in some elements in elementary school music teaching. These are: Free Improvisational Music Therapy, Orff Music Therapy, Paraverbal Music Therapy, Experimental Improvisational Music Therapy, and Creative Music Therapy (Nordoff Robbins Music Therapy).

Free Improvisational Music Therapy is a method developed by Juliette Alvin (1978). The method was initially implemented on chil- 
dren with autism and later on children with other disabilities, as well as adults. A characteristic of this method is the fact that nothing is imposed by the therapist, which in return allows the patient to relax completely. The model is based on the

“... philosophy that music is a potential space for free expression with no guidelines or confinements to musical and expressional rules. Free improvisation gives freedom to use any musical activity, play any instrument, and make sounds in any way, without a previous training or evaluation and judgment by aesthetic criteria." (Nemesh, 2017, 170)

The model can be used individually, in a form of a family group or a group, depending on the specific developmental needs of each individual. The therapist chooses an instrument for improvisation according to the patients' interests. The goal is to achieve self-relaxation, establish different types of relationships with one's environment or support the development of physical, intellectual, and socio-emotional abilities (Bruscia, 1988; Škrbina, 2013).

Orff Music Therapy is based on the Orff-Schullwerk concept (Orff, 1963/2011; Voigt, 2003). The concept was developed by the German composer Carl Orff, who emphasized that music should be taught in an active and creative way, and that children should participate in music activities in a non-competitive atmosphere for the pleasure they feel while performing. The starting point for Orff is rhythm, which is performed or improvised on various percussion instruments. Melodic material is initially based on only three tones (so-mi-la). Later on, this expands to include pentatonic and major scales. In Orff-Schulwerk, Orff develops his idea of elemental music that is associated with movement, dance, speech, and a great deal of improvisation:

"What then is elemental music? It is never music alone, but a unity with movement, dance and speech. It is music that one makes, in which they take part not as listeners, but as participants. It is unsophisticated, employs no big forms and no big architectural structures, and it uses small sequence forms - ostinato and rondo. Elemental music is near the earth, natural, physical, within the range of everyone to learn it and experience it and it's also suitable for a child." (Orff, 1963, cited in: Shamrock, 1995, 8)

This approach to music is also present in Orff Music Therapy. The method was created at the initiative of Theodor Hellbrïgge and Gertrude Orff (Voigt, 2003). They used

“... elemental music as a creative stimulus for a child, enabling him to experience his own possibilities for development within the musical situation and 
musical interaction with others. Making music spontaneously (improvising) was, and is, a central means of interacting in Orff Music Therapy." (Voigt, 2013, 99)

Improvisation includes songs, dance, games, and lyrics. Rhythm also plays an important role in this method and it is recommended to use the Orff instrument when performing music activities. Playing instruments can further enhance relaxation, coordination, and sensory perception development (tactile, optical, spatial or acoustic) (Voigt, 1999). In Orff Music Therapy, children are encouraged to improvise with music by creating spontaneously their musical response to an initial musical idea that can be sound, rhythm, movement or melody. Alternating between group playing and the improvisation of one child is often used (Bruscia, 1988).

Paraverbal Music Therapy should also be mentioned "as a means of communication, an approach that employs a variety of maneuvers for nonverbal communication in addition to ordinary speech" (Heimlich, 1981, 262). This method, developed by Evelin Heimlich, was originally intended for children who do not respond to verbal therapy methods, and who have certain emotional or communication problems. Paraverbal music therapy uses both nonverbal and verbal channels of communication, and employs various expressive media. Assuming that these children would feel more intrigued and less threatened by a nonverbal approach, the therapy uses the music components (tempo and pitch), miming, movement, and art to help children express themselves (Bruscia, 1988; Heimlich, 1965; 1980; 1983; Nikmanesh, 2012; Wheeler, 1987). The individual seeks to engage in some form of paraverbal expression or communication in order to "fulfill the client's basic emotional needs, develop a sense of self, foster self-expression and communication, as well as to provide relief from painful emotions and eliminate their symptoms" (Bruscia, 1988, 12). Several different activities are used within this method, such as improvisational stories, improvisational singing, improvisational rhythmic dialogues, introducing instruments, playing instruments together, metaphorical use of songs, metaphorical use of instruments, reciprocal rhythmic movement, drawing or painting with music, mimicry, playing games and dramatic activities (Bruscia, 1988).

Experimental Improvisational Music Therapy is a model developed by Anne Riordan and Kennet E. Bruscia in 1972 (Bruscia, 1988). Ri- 
ordan originally conceived of experimental improvisation therapy as a method for using dance to help disabled individuals develop creativity, self-expression, and interpersonal skills. Bruscia adapted experimental improvisation for music therapy (Bruscia, 1988). The method involves dance improvisation, musical improvisation, and verbal discussion. In doing so, certain variables remain constant while others change:

"Through improvisation, everyone contributes a part of themselves, which creates a sense of belonging and comfort. Everyone's input is valued and important to the outcome. As a result, players are often more involved in forming collaborative relationships with each other than, if asked, to conform to the rules that come from an outside source or authority. As improvised music making has a potential to be a catalyst for the formation of intimate relationships, based in authentic expression and communication, it is at the core of many music therapy models." (Das, 2011, 9)

The method is implemented in a group and is intended for work with both children and adults who have certain difficulties, as well as for work with children and adults who do not have any difficulties. The method seeks to improve social, emotional, cognitive, and physical abilities of a child or an adult and enhance the potential for self-expression and creativity.

Creative Music Therapy (Nordoff Robbins Music Therapy) was developed by Paul Nordoff and Clive Robbins under the influence of Rudolf Steiner's ideas - the founder of anthroposophy and Waldorf pedagogy (Carlgren, 1976/2008). This method was originally intended for children. Although group-work is also very important in creative music therapy method, the emphasis is placed on individual therapy, because it addresses the specific needs of each individual child.

Both individual and group music therapy use active music making in a creative and interactive way. During individual therapy, the patient usually uses two media - mainly singing and playing the drums and cymbals, and other instruments if needed. In group therapy, the patient sings, improvises with different types of percussion and string instruments and participates in a specially composed musical drama. During group therapy sessions, children collaborate in making music, developing skills, musical achievements, sharing experiences and self-expression (Nordoff and Robbins, 1977; 1983). The main goals to be pursued, when using Creative Music Therapy, are developing self-expression, communication, and interpersonal relationships, building a more stable 
personality, improving creativity, and eliminating pathological patterns of behavior (Bruscia, 1988):

"Emotions sometimes build something like a crescendo or accelerando inside people, or they can come at us suddenly as in an accented cymbal crash. When clients in music therapy develop these skills relevant to the expressive dimensions of music, they are simultaneously developing the capacity to, first tolerate, and then, enjoy the full realm of human emotional experience. Instead of being imprisoned by a paucity of emotional experience, they become liberated by the ability to fully experience their humanity as represented in emotional experience." (Aigen, 2014, 22)

What all of the music therapy methods described above share is that they are based on an active approach and musical improvisation. As a part of music therapy, children can play, improvise, create or listen to music. Activities can be carried out individually or in a group. Individual work is used for children who are unable to function in a group or who interfere with group work. Such activities are approached very flexibly, in accordance with the needs of an individual child (Nordoff $\&$ Robbins, 1977). In group music therapy, children sit in a circle in a group of, ideally, four to eight. The music therapist most often plays the piano or guitar, and children play instruments they can hold in their hands. These can be claves, maracas, drums, xylophones or some other percussion instruments. Children often have individual performances and are free to improvise on a selected musical instrument.

\begin{abstract}
“The session starts with a 'Hello' song, which serves as a transitional function from previous classroom activities, and ends with a 'Good Bye' song that gives a sense of closure to the musical experience. Within this established structure, various activities take place during the middle of the session, including singing songs, playing instruments, and moving to the beat of the music." (Pellitteri, 2000, 382-383)
\end{abstract}

\title{
Methods
}

\section{Research objectives}

The aim of the research was to establish communication among the pupils in regular classes by using the elements of various models of improvisational music therapy. The aim was also to show the primary education teachers how the elements of music therapy models can be implemented with children in their regular classes, not only children 
with disabilities, to introduce teachers to the examples of music activities, and show how activities involving music improvisation can integrate special needs children into music teaching.

\section{Research participants}

The research involved 20 third-year pupils at Fran Krsto Frankopan Elementary School in Osijek, Croatia in the 2016/2017 school year. The sample was not random, i.e. it was relevant. The selectivity embedded in random samples springs from the researcher's choice of a particular target group, with the full awareness that it does not represent the general population. This is often the case in smaller-scale research, in research conducted in one or two schools, with two or three groups of pupils, or with a special group of teachers where there is no intention to generalise (Cohen et al., 2000).

The study was conducted in accordance with the Code of Ethics for Research with Children, adopted by the Croatian Government's Council for Children in 2003. It is the task of the Children's Council to promote and protect the rights of children according to the Convention on the Rights of the Child (1989). In accordance with the Code of Ethics for Research with Children, parents and guardians provided written consent for children to participate in the study. Parents and guardians also gave their written consent for the audio and video recording of teaching activities in which their children participated. They were informed about the purpose of the research, its general and specific benefits and the type and duration, the confidentiality of the data obtained, the privacy of participants, voluntary participation, and the right to withdraw from the research. We also explained its purpose and methods to the children involved in a manner appropriate to their age.

\section{Methodological approach}

Our research began with the interpretative paradigm, characterized by a focus on a deeper understanding of the phenomena being studied (Cohen, Manion and Morrison, 2000). In the field of education, this refers to the activity of man and his behavior, starting from the frame reference of the subject himself. This implies the pursuit of subjectivity as well as allowing for a more complete, richer interpretation of phenomena based on valid, i.e. 'real', 'rich' data (Mužić, 1999). The research is 
empirical and was conducted in a primary school. We used a systematic observation process to collect data, i.e. participatory observation. In this process, the observer consciously and systematically engages in the activities, interests and emotions of the group he or she observes. The information obtained through this approach is generally more reliable and truthful than that of an "external" observation. This eliminates the respondents' sense that they are the objects of control, thus contributing to the reality of the observed situation (Mužić, 1999). We used the systematic observation protocol and a reflexive diary as an instrument, in which the observations were recorded. Then, the data were processed and analyzed. We used a qualitative analysis to determine what was happening and how. We reduced the data obtained through observation, which means that we kept everything that was relevant to the topic of research and eliminated everything that was irrelevant. Some figures were presented in numerical terms, but qualitative statements remained at the forefront.

\section{Results}

\section{Description of activity}

In order to achieve the set goals, six improvisational music activities were conducted with pupils during musical culture classes, one activity each week. After each activity, pupils expressed their opinions on the activity carried out through the evaluation. In the evaluations, pupils were able to express how they felt during the activity and whether something in particular made them happy or sad.

The goal of this research is to show how various methods of music therapy - with some adjustments - can be used in regular classes. These activities include some of the elements of certain music therapy methods, although they all come together during each activity. The emphasis was placed on the elements that may help pupils strengthen their physical, mental, social, and emotional health. We included the aspect of Free Improvisational Music Therapy by which no limitations are placed on children during musical activities, allowing them to relax and use their voice or an instrument in their own way. Therefore, we attempted to allow children to achieve self-liberation, i.e. the development of physical, intellectual, and socio-emotional abilities. From Orff Music Therapy we adopted a game involving rhythms and combinations of movement and singing (using the body as an instrument). Movement is intended to 
serve as communication through music, with the aim of enabling pupils to experience their own development prospects within a musical situation and to communicate musically with other pupils. The element taken from Paraverbal Music Therapy was improvisational singing, which also helps with communication problems among pupils. The elements of music and dance were taken from Experimental Improvisational $\mathrm{Mu}$ sic Therapy which have the potential to evoke a sense of satisfaction and happiness and create a positive classroom atmosphere. Singing and improvisation with various types of percussion instruments were taken from Creative Music Therapy (Nordoff Robbins Music Therapy) to encourage pupils to self-express, develop communication skills, and good interpersonal relationships.

\section{First activity}

The first activity to help pupils relax was conducted at the very beginning of our meeting to get to know each other better, and to improve communication during other meetings. The activity applies the elements of Free Improvisational Music Therapy. For improvisation, pupils were instructed to use their voice any way they like, allowing them to relax and sing their name in any way they want. The pupils were given percussion instruments and sat in a circle. Each pupil sang his or her name by improvising a melody while performing a rhythm on the instrument. Afterwards, the pupils performed other musical improvisations. They could sing a melody by means of saying words they could use to describe where they live, who their best friend is, etc. By playing the percussion they could follow their singing. This activity fitted well at the beginning of the session, as each pupil had the opportunity to introduce themselves and get to know the others.

\section{Evaluation}

During the evaluation, ballpoint pen was used as a mimed object symbolically representing a microphone. Several pupils briefly answered questions about how they felt during the activity, whether they liked it and whether they would like to repeat it.

"After meeting the pupils, I briefly described what we would be doing over the next six hours. At the very mention of the musical activity, they cheered 
and said that they love music classes. We began the activity with me singing my name, followed by all of the pupils singing their own names. After this, each of the pupils sang what they love to do most. They mostly sang that they like to play. They worked well, they were active and highly engaged. After the activity itself, we carried out an evaluation in which I randomly asked pupils questions using a 'microphone' (ballpoint pen). When asked how they felt during the activity, they answered that they felt good, that the activity was enjoyable, and that they liked it. When asked if they would like to repeat the activity, they replied that they would be happy to do it. In the first activity, one pupil stood out more than the others; he was more active than the rest and always in the spotlight. During the singing of names, a girl stood out who sang her name very well, in good intonation, and most importantly, she did not copy the other pupils, but rather invented her own melody." (Records from the reflexive diary)

\section{Second activity}

The second activity was a combination of dancing and singing. We combined movement with singing, which is a characteristic of Orff Music Therapy. During this activity, we used body as an instrument; pupils clapped their hands, snapped their fingers, etc. Musical movement served as a communication tool for the pupils, and communication is what is particularly significant for achieving a specific therapeutic effect. For this activity, pupils were divided into groups. Each group was tasked with composing a musical unit using their body as an instrument to play a song delegated by the teacher. After the pupils had conceived the musical unit, they presented it as a group in the classroom.

\section{Evaluation}

After the second activity, we selected an evaluation method in which pupils were asked to color in a face that represents the feeling triggered by a musical activity they had just performed (Figure 2). Each pupil could choose multiple emotions depending on how they felt at that moment. 


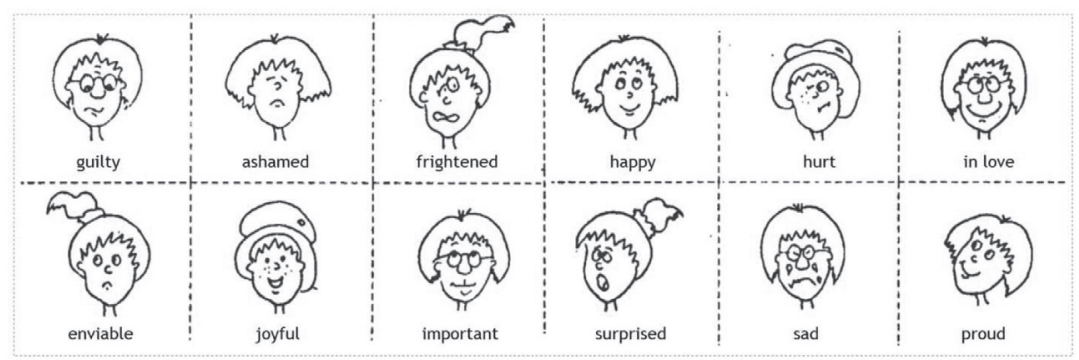

Figure 2. Evaluation sheet of feelings (1)

\begin{abstract}
"Before entering the class, the pupils were excited about the next activity. After we sat in a circle, I told each pupil one number; then, they split into four groups according to these numbers. I was pleasantly surprised by their behavior. Without complaining, they split into groups and waited for my instructions. Once I gave them instructions, which they listened to carefully, they immediately started working and were very highly engaged. The pupils instantly understood the task and did not seek any help. When all the groups were ready, they were able to present their work. The pupils did a great job in groups and encouraged each other. Each group was different, creative, and did not copy the other groups. At the end of the activity, I handed them the evaluation sheets, which they filled in at their usual seats. They found it very interesting, and they were looking forward to the next activity." (Records from the reflexive diary)
\end{abstract}

\title{
Third activity
}

In the third activity, we applied the element from Paraverbal Music Therapy. This method was chosen as it also helps with communication problems among pupils. The pupils worked on their communication, completed the assignment, and presented it to the whole class. They were given a task to compose a new tune for the rhymes given. The pupils were divided again into several groups. They were presented with the rhymes and their task was to put those rhymes into practice. They could use familiar tunes or devise new ones. After the pupils had composed the musical unit, they presented it as a group in front of the class. 
Rhymes

Enci, benci, na kamenci,

Troja vrata zapečata,

Eri keri muzikeri, keč.

Engel, bengel, čiko či,

Čiči, riči, bombardi,

Čika, čoka, tužba roka,

Vani si ga ti.

\section{Evaluation}

During the evaluation, pupils answered the following questions:

1. How did you feel during the activity?

2. Did something in particular make you happy?

3. Did something in particular make you sad?

"Pupils accepted the third activity with approval and joy. After I distributed the tasks, I had to give them some more information so they could complete the task on their own. During this activity, the pupils were active, creative, and did their best. Each group performed what they had composed. The pupils were very pleased with their own achievements. The activity was extremely interesting to them because it allowed them to express themselves in a way they love very much, which was through music." (Records from the reflexive diary)

\section{Fourth activity}

Experimental Improvisation Music Therapy is a model of group therapy that includes music and dance. This kind of dance improvisation is good, not only for children with disabilities, but for all children in fulltime teaching. In addition to stimulating physical activity, dance evokes a sense of satisfaction, happiness and creates a positive atmosphere in the classroom that we were convinced of while conducting the activity. At the beginning of the fourth activity, we repeated the song Veseljak (Jolly Fellow) with the pupils and taught them the dance steps. The pupils had to spread out across the classroom so that each of them had enough space. Along with the lyrics, they performed the following steps:

Veseljak (Jolly Fellow)

Ja sam ptica crna / I am a black bird (pupils should perform two jumps forward) 
A žut mi je nos / And yellow is my nose (pupils should turn around and lean over)

Svako dijete znade / Every child knows (pupils should perform two jumps back)

Da se zovem kos / That my name is blackbird (pupils should turn around and lean over)

After the pupils had successfully completed all the steps, they were given a new assignment - to compose dance steps for the other stanzas of the song on their own. One pupil would go out in front of the other pupils, show the steps, and all the others would repeat it. This was repeated several times.

\section{Evaluation}

For this activity, an evaluation sheet (Figure 3) was given in which they were to mark the image that most accurately described their feelings while performing the activity.

\begin{tabular}{|l|l|}
\hline I felt comfortable. It was pleasant. \\
\hline I felt fine. I was bored. \\
\hline I felt uncomfortable. \\
\hline
\end{tabular}

Figure 3. Evaluation sheet: weather forecast 
"I was pleasantly surprised at how well these third-year pupils had learned to sing songs in previous years. They proved this with song 'Veseljak', for which they had to compose dance steps. They quickly understood the task, but the activity did not go as smoothly as the previous ones, because the pupils who showed the steps had various ideas that were hard to implement. They all worked hard and were active, creative, and innovative. Some pupils found it difficult to follow the steps, but everything went well in the end." (Records from the reflexive diary)

\section{Fifth activity}

Rhythm is an important tool in Orff Music Therapy. The fifth activity uses these elements of Orff Music Therapy. The activity began with the teacher clapping a rhythmic phrase and the pupils repeating it. After that, any pupil, who wanted to, could stand in front of the board and provide a new original rhythmic phrase. This was, then, repeated by all the pupils, so several pupils interchanged. After this, the teacher began a new rhythmic phrase by clapping, which was then "passed on" across the classroom from one pupil to another until everyone clapped the phrase.

\section{Evaluation}

During the evaluation, pupils were given a leaflet containing words that describe feelings (Figure 4). Pupils were required to color the words that best described their feelings during the activity.

\section{Color the words that best describe your feelings during the activity.}

SADNESS JOY DELIGHT

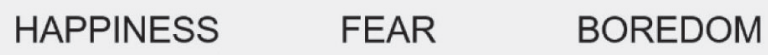

INSECURITY

\section{SUCCESS}

Figure 4. Evaluation sheet of feelings (2) 


\begin{abstract}
"At the very mention of the next activity, which was clapping rhythmic phrases, the pupils were very happy and excited, even though they had already done this activity with their teacher. The entire activity went very well. The pupils listened the instructions carefully, repeating the rhythmic phrases correctly, listening and correcting other pupils as needed. All the pupils understood the task - they did a great job, except for one girl, about whom the teacher had warned me, that would likely be unable to complete the task well. Pupils who assisted me in demonstrating the task to the others, were happy to be able to participate in this way." (Records from the reflexive diary)
\end{abstract}

\title{
Sixth activity
}

The sixth activity was a combination of the elements of two methods of music therapy. As in the second activity, we also used the elements of Orff Music Therapy in the sixth and final activity. Pupils used Orff Instrumentation to play the song. They used drums, claves, maracas, etc. Pupils also improvised with different types of instruments and participated in a pre-composed musical unit, which is a characteristic of both Orff Music Therapy and Nordoff Robbins Music Therapy. At the beginning of the activity, the teacher repeated the familiar song with the pupils. After repeating the lyrics and melody of the song, the teacher explained the task, which was to reorganize the song by changing its tempo and dynamics. The pupils then split into groups. The tempochanging group also played the instruments, while the dynamics-changing group sang a song.

\section{Evaluation}

During the evaluation, each pupil was given a sheet with four statements (Table 1), followed by the answers "I agree" and "I disagree". The pupils were required to read the statements carefully and tick the answer that best suited them after the activity. The claims were: "I was feeling well today and I am happy"; "I found the task interesting and would love to do it again"; "I was bored and uninterested"; "I didn't feel comfortable".

"The fact that the pupils were sad that it was the last day proves how much they enjoyed all of the activities. I can safely say that the final activity was much more difficult than the others, and that I was concerned whether the pupils would understand the task and be able to complete it. After I distributed the tasks, I gave them additional instructions, to which they reacted po- 
sitively. The task was more difficult for the group that changed the tempo of the song than for the group that was changed the dynamics, and their degrees of success differed as a result. Also, there was no agreement in the second group. Specifically, one girl was clearly of a different opinion, but these disagreements were eventually resolved. The pupils performed well on the task, although changes were more noticeable in the dynamics than in the tempo of the song. At the end of the activity, the most important thing was that they had a good time, that they sang and played, expressed their creativity, and developed their imagination. Afterward, I asked them if they found the task difficult; they replied that it was not. The evaluation proved that the pupils felt good in class." (Records from the reflexive diary)

As emphasized above, we find elements of different methods of music therapy in every musical activity that is conducted with the pupils. Each of these methods aims to develop the emotional, and social needs of the child. We believe that primary and secondary school teachers should introduce more activities like these not only into music teaching, but also into non-music subjects. These musical activities greatly facilitate the integration of children with disabilities into regular classes and foster a positive classroom atmosphere. During and after the activity, the pupils expressed an apparent cheerful mood, relaxation, and satisfaction for having had an opportunity to display their creativity, imagination, and personality.

\section{Evaluation results}

After each activity, we also conducted an evaluation to measure any potential positive impact of improvisational music activities on the pupils. The results of each evaluation are presented separately below. Evaluation for the first activity was oral; we asked ten pupils how they felt during the activity and whether they would repeat it. The results showed the following: nine pupils stated that they felt good during the activity and that they would be happy to repeat it. Only one pupil stated that he felt fine, but might not repeat the activity.

In the evaluation conducted after the second activity, pupils were required to circle the feelings that best described how they felt while participating in the activity. Table 1 lists the most common feelings the pupils circled. All pupils (except for one pupil who was absent) circled 'happy', 17 circled 'joyful', and nine circled 'proud'. The table also shows that seven pupils felt surprised, two felt important, whereas one felt in love, one felt guilty and one enviable. 
Table 1. Pupils' feelings after participating in the second activity

\begin{tabular}{|c|c|}
\hline Pupil response & $\boldsymbol{f}$ \\
\hline Happy & 19 \\
\hline Joyful & 17 \\
\hline Proud & 9 \\
\hline Surprised & 7 \\
\hline Important & 2 \\
\hline In love & 1 \\
\hline Guilty & 1 \\
\hline Enviable & 1 \\
\hline
\end{tabular}

The evaluation of the third activity was to answer three questions: how pupils felt during the activity, whether something had made them happy, and whether something had made them sad. To the first question, pupils answered that they felt cheerful, delighted, good, great, happy, playful, surprised, and entertained, which was all evident during the activity. To the next question (whether something in particular had made them feel happy), most pupils responded that they were very happy with the singing, while some enjoyed the rhythm and some enjoyed the rhymes. Some wrote that nothing had pleased them particularly. To the last question (whether something had made them feel sad), all pupils answered negatively.

The fourth activity was followed by an evaluation in which the pupils had to circle an image with a description that most accurately described how they felt during the activity. They were offered five statements that read: "I felt great! I learned something new!", "I felt comfortable. It was pleasant", "I felt fine. I was bored." "I felt uncomfortable." And "I felt scared and found it uninteresting." Pupils had to circle which statement suited them best. A total of 18 pupils circled that they felt great and learned something new, and one pupil circled that he felt comfortable and found it pleasant.

As a part of the fifth evaluation, pupils were asked to color the word that most accurately described their mood during the activity. Table 2 shows that pupils colored feelings of delight, joy, happiness, and success. This information is a good indicator that the activity was successful. 
Table 2. Pupils' feelings after participating in the fifth activity

\begin{tabular}{|c|l|}
\hline Pupils response & $\boldsymbol{f}$ \\
\hline Delight & 19 \\
\hline Joy & 18 \\
\hline Happiness & 18 \\
\hline Success & 17 \\
\hline
\end{tabular}

The results in Table 3 show that the pupils agreed they felt good during the activity and that they were happy, found it interesting, and would be happy to repeat the activity. We can also see that they were not bored or uninterested and that they did not feel uncomfortable. The exception is one pupil who disagreed with the sentence "I found it interesting and would love to do it again."

Table 3. Pupils' feelings after participating in the sixth activity

\begin{tabular}{|c|l|c|c|}
\hline & \multicolumn{1}{|c|}{ Statements } & Agree & Disagree \\
\hline 1 & Today I felt good and I was happy. & 20 & 0 \\
\hline 2 & $\begin{array}{l}\text { I found it interesting and I would love } \\
\text { to do it again. }\end{array}$ & 19 & 1 \\
\hline 3 & I was bored and uninterested. & 0 & 20 \\
\hline 4 & I didn't feel comfortable. & 0 & 20 \\
\hline
\end{tabular}

Based on the results of the evaluations, we can conclude that all the activities were successful. All the evaluations showed that the pupils were comfortable and happy to participate in all the activities.

\section{Conclusion}

The Croatian Primary Music Curriculum (2006) places special emphasis on the aesthetic education of pupils within the music teaching and emphasizes that this kind of education is best achieved through music listening activity and becoming familiar with music. Other activities (singing, playing an instrument, musical games and musical creativity) are placed in the background, and the question of choosing the way of conducting music performance activities is left to the teacher "according to the principle of real feasibility and possibilities of musically 
relevant reach" (Primary Music Curriculum, 2006, 66). This means that teachers, if they want, can omit some of the listed musical activities from music teaching altogether.

The results of the previous research show that active involvement in music is important for pupils. Through involvement in singing, playing instruments, musical games, and musical creativity, not only do the pupils develop their musical abilities, but they also develop intellectual and motor skills and improve their emotional, psychological, and social development (Hallam, 2010; Rabinowitch et al., 2013; Schellenberg, 2004; 2005; Welch et al., 2014). Such methods are also achieved via active music therapy methods. The aim is to involve children in interaction to the greatest extent possible, to enable them to express themselves musically, and allow them to communicate through music. Simultaneously, working methods and the means of expression should be adapted to each individual child's needs to the greatest possible extent (Bruscia, 1988; Nikmanesh, 2012; Svalina, 2009; Voigt, 2013).

The results of our research show that activities from certain methods of music therapy have a place in music teaching. During these musical activities, pupils develop their musical abilities, but also communicate through music and develop social interaction with other pupils. The pupils displayed imagination, creativity and willingness to work together in order to achieve a common goal when performing musical activities. In the aftermath of each activity, pupils expressed satisfaction, happiness and joy, which they displayed in their evaluations. The pupils were comfortable, happy to participate in all activities, and successfully communicated through music. Observations of the activities performed highlighted their independence in work and cooperation in the implementation of the task.

If we want to contribute to the overall development of pupils in music teaching, it is necessary to acquaint current and future teachers, with certain music therapy methods and ways of carrying out musical activities within certain methods. Children can encounter music in many different ways, but an active approach through musical play and improvisation enables even children with severe developmental disabilities to reach their potential. We hope that this paper will serve as an incentive for teachers to use active improvisational methods of music therapy in music teaching in order to better integrate the pupils with special needs, as well as to foster personal growth and development in pupils without special needs. 


\section{References}

Aigen, Kenneth (2014), "Music-centered dimensions of Nordoff-Robbins music therapy", Music Therapy Perspectives, 32(1), pp. 18-29.

doi: https://doi.org/10.1093/mtp/miu006

Alvin, Juliette (1978), Music Therapy for the Autistic Child, London: Oxford University Press.

Bruscia, Kenneth E. (1988), “A survey of treatment procedures in improvisational music therapy," Psychology of Music, 16, pp. 1-24.

doi: https://doi.org/10.1177/0305735688161002

Carlgren, Frans (1976/2008), Education towards Freedom. Rudolf Steiner Education: A Survey of the Work of Waldorf Schools Throughout the World, East Grinstead, Sussex, England: Lanthorn.

Cohen, Louis; Manion, Lawrence; Morrison, Keith (2000), Research Methods in Education (5th ed.), London: Routledge Falmer.

Convention on the Rights of the Child (UNCRC) (adopted 20 November 1989, entered into force 2 September 1990) 1577 UNTS 3.

Das, Kalani (2011), The Way of Music: Creating Sound Connections in Music Therapy, Denton, TX: Sarsen Publishing.

Hallam, Susan (2010), "The power of music: Its impact on the intellectual, personal and social development of children and young people," in: Hallam, S. and Creech, A. (eds.), Music Education in the 21st Century in the United Kingdom, Institute of education, London: University of London, pp. 2-17. doi: https://doi.org/10.1177/0255761410370658

Heimlich, Evelin Phillips (1965), "The specialized use of music as a mode of communication in the treatment of disturbed children," Journal of the American Academy of Child Psychiatry, 4(1), pp. 86-122.

doi: https://doi.org/10.1016/S0002-7138(09)62072-0

Heimlich, Evelin Phillips (1980), "Paraverbal techniques: A new approach for communication with children having learning difficulties," Journal of learning disabilities, 13(9), pp. 16-18. doi: https://doi.org/10.1177/002221948001300904

Heimlich, Evelin Phillips (1981), "Patient as assistant therapist in Paraverbal therapy with children," American Journal of Psychotherapy, 35(2), pp. 262-267. doi: https://doi.org/10.1176/appi.psychotherapy.1981.35.2.262

Heimlich, Evelin Phillips (1983), "The metaphoric use of song lyrics as Paraverbal communication," Child Psychiatry and Human Development, 14(2), pp. 67-75. doi: https://doi.org/10.1007/BF00707671

Hurwitz, Irving; Wolff, Peter H.; Bortnick, Barrie D.; Kokas, Klara (1975), "Nonmusical effects of the Kodály Music Curriculum in primary grade children," Journal of Learning Disabilities, 8, pp. 45-51.

doi: https://doi.org/10.1177/002221947500800310 
Jensen, Eric P. (2008), Super Teaching: Over 1000 Practical Strategies (4th ed.), Thousand Oaks, CA: Corwin.

Kim, Jinah (2016), "Psychodynamic music therapy," Voices, 16(2). doi: https://doi.org/10.15845/voices.v16i2.882

Mužić, Vladimir (1999), Uvod u metodologiju istraživanja odgoja i obrazovanja [Introduction to the methodology of education research], Zagreb: Educa.

Nemesh, Beth (2017), "Family-based music therapy: From dissonance to harmony," Nordic Journal of Music Therapy, 26(2), pp. 167-184. doi: https://doi.org/10.1080/08098131.2016.1144638

Nikmanesh, Leila (2012), "Effects of Paraverbal music therapy on emotional intelligence in young children: An experimental study," Journal of American Science, 8(10), pp. 145-151.

Nordoff, Paul; Robbins, C. (1977), Creative Music Therapy: A Guide to Fostering Clinical Musicianship (2nd ed., revised and expanded), Gilsum, NH: Barcelona.

Nordoff, Paul; Robbins, Clive (1983), Music Therapy in Special Education (2nd ed.), St. Louis: MO: MMB Music.

Orff, Carl (1963/2011), “Orff-Schulwerk: Past \& Future” (M. Murray, trans.), in: Haselbach, B. (ed.), Texts in Theory and Practice of OrffSchulwerk, Vol. 1, Mainz, Germany: Schott, pp. 134-159 (reprinted from Orff-Institut, Jahrbuch, May 1963).

Pellitteri, Johnn (2000), "Music therapy in the special education setting," Journal of Educational \& Psychological Consultation, 11(3-4), pp. 379-391. doi: https://doi.org/10.1207/S1532768XJEPC113\&4_06

[Primary School Curriculum] Nastavni plan i program za osnovnu školu (2006), Zagreb: Ministarstvo znanosti, obrazovanja i športa.

Rabinowitch, Tal-Chen; Cross, Ian; Burnard, Pamela (2013), "Long-term musical group interaction has a positive influence on empathy in children," Psychology of Music, 41, pp. 484-498. doi: https://doi.org/10.1177/0305735612440609

Rauscher, Frances H.; Shaw, Gordon L.; Levine, Linda J.; Ky, Katherine N.; Wright, Eric L. (1994), "Music and spatial task performance: A causal relationship," paper presented at the meeting of the American Psychological Association, CA, Los Angeles.

Rickard, Nikki S.; Appelman, Peter; James, Richard; Murphy, Fintan; Gill, Anneliese; Bambrick, Caroline (2013), "Orchestrating life skills: The effect of increased school-based music classes on children's social competence and selfesteem," International Journal of Music Education, 31, pp. 292-309. doi: https://doi.org/10.1177/0255761411434824

Rojko, Pavel (2012), Metodika nastave glazbe. Teorijsko-tematski aspekti [Methods of Music Teaching. Theoretical-thematic Aspects], Osijek: Sveučilište Josipa Jurja Strossmayera. 
Shamrock, Mary (1995), Orff Schulwerk: Brief history, description and issues in international dispersal, Cleveland, $\mathrm{OH}$ : American Orff-Schulwerk Association.

Schellenberg, E. Glenn (2004), "Music lessons enhance IQ," Psychological Science, 15, pp. 511-514. doi: https://doi.org/10.1111/j.0956-7976.2004.00711.x

Schellenberg, E. Glenn (2005), "Music and cognitive abilities," Current Directions in Psychological Science, 14(6), pp. 317-320.

doi: https://doi.org/10.1111/j.0963-7214.2005.00389.x

Schlaug, Gottfried; Norton, Andrea; Overy, Katie; Winner, Ellen (2005), "Effects of music training on the child's brain and cognitive development," Annals New York Academy of Sciences, 1060, pp. 219-230.

doi: https://doi.org/10.1196/annals.1360.015

Svalina, Vesna (2009), "Glazboterapija i djeca s posebnim potrebama" ["Music therapy and children with special needs"], Tonovi, 53, pp. 144-153.

Svalina, Vesna (2015), Kurikulum nastave glazbene kulture i kompetencije učitelja za poučavanje glazbe [Music Curriculum and Teachers' Competences for Music Teaching], Osijek: Sveučilište Josipa Jurja Strossmayera u Osijeku, Fakultet za odgojne i obrazovne znanosti.

Swanwick, Keith (2003), A Basis for Music Education, London: Routledge. doi: https://doi.org/10.4324/9780203422434

Škrbina, Dijana (2013), Art terapija i kreativnost [Art therapy and creativity], Zagreb: Veble Commerce.

Voigt, Melanie (1999), "Orff music therapy with multi-handicapped children," in: Wigram, T.; de Backer, J. (eds.), Clinical Applications of Music Therapy: Developmental Disability, Paediatrics and Neurology, London: Jessica Kingsley Publishers.

Voigt, Melanie (2003), "Orff music therapy. An overview," Voices: A World Forum for Music Therapy, 3(3). doi: https://doi.org/10.15845/voices.v3i3.134

Voigt, Melanie (2013), "Orff music therapy: History, principles and further development," Approaches: Music Therapy \& Special Music Education, 5(2), pp. 97-104.

Weber, Ernst Waldemer; Spychiger, Maria; Patry, Jean-Luc (1999), “Glazba čini školu," Tonovi, 34, p. 3.

Welch, Graham F.; Himonides, Evangelos; Saunders, Jo; Papageorgi, Ioulia; Sarazin, Marc (2014), "Singing and social inclusion," Frontiers in Psychology, 5, p. 803. doi: https://doi.org/10.3389/fpsyg.2014.00803

Wheeler, Barbara L. (1987), "The use of paraverbal therapy in treating an abused child," The Arts in Psychotherapy, 14(1), pp. 69-76. doi: https://doi.org/10.1016/0197-4556(87)90036-0 


\title{
MOGUĆNOST PRIMJENE ELEMENATA GLAZBOTERAPIJE U NASTAVI GLAZBE
}

\author{
Martina Metić, Vesna Svalina
}

Novijaznanstvena istraživanja pokazuju da uključivanje djece uglazbene aktivnosti utječe na njihov psihički, emocionalni $i$ socijalni razvoj zbog čega se glazba sve više koristi $i$ u medicinske, odnosno terapeutske svrhe. Kako bismo saznali je li moguće neke elemente iz pojedinih metoda glazboterapije primijeniti i u nastavi glazbe u osnovnoj općeobrazovnoj školi, proveli smo kvalitativno istraživanje u kojemu su sudionici bili učenici tré́eg razreda jedne osnovne škole iz Osijeka. Za potrebe prikupljanja podataka koristili smo postupak sustavnog promatranja, a za analizu podataka kvalitativnu i kvantitativnu analizu. Rezultati istraživanja pokazali su da je uvođenje elemenata iz pojedinih metoda glazboterapije moguće te da učenici rado sudjeluju u svim provedenim aktivnostima. Pritom učenici iskazuju maštovitost, kreativnost, samostalnost u radu te spremnost na suradnju.

Ključne riječi: nastava glazbe, primarno obrazovanje, glazboterapija, improvizacijski modeli glazboterapije, glazbene aktivnosti 